\title{
PENGARUH SISTEM OLAH TANAH DAN RESIDU PEMUPUKAN N JANGKA PANJANG TERHADAP LAJU RESPIRASI TANAH PADA PERTANAMAN KACANG TUNGGAK (Vigna unguiculata $($ L.) DI POLITEKNIK NEGERI LAMPUNG PADA MUSIM KE-32
}

\section{EFFECT OF TILLAGE SYSTEM AND LENGTH NITROGEN FERTILIZING RESIDUE SYSTEM FOR SOIL RESPIRATION RATE IN COWPEA CROPPING (Vigna unguiculata (L.) AT POLYTECHNIC STATE OF LAMPUNG IN THE $23^{\text {rd }}$ SEASON}

\author{
Elpin Wahyu Illahi ${ }^{1 *}$, Ainin Niswati ${ }^{2}$, Henrie Buchari $^{2}$ dan Sri Yusnaini ${ }^{1}$ \\ ${ }^{1}$ Jurusan Agroteknologi Fakultas Pertanian Universitas Lampung, Bandar Lampung, Indonesia \\ ${ }^{2}$ Jurusan Ilmu Tanah Fakultas Pertanian Universitas Lampung, Bandar Lampung, Indonesia \\ *Email: 3lp1n96@gmail.com \\ * Corresponding Author, Diterima: 21 Apr. 2021, Direvisi: 17 Mei 2021, Disetujui: 5 Ags. 2021
}

\begin{abstract}
One of effort to maintained the fertile of soil is by better maintenance of soil that also according to the rules of sustainable agriculture that carried out proper conservation and fertilization land management. The purpose of this study was to studied the effect of long-term tillage system, long-term $N$ fertilization residue, also the effect of interactions long-term tillage system and $N$ fertilization residues on soil respiration rate, moreover studied the relations between soil C-organic, soil moisture content, soil pH, and soil temperature with soil respiration rate in cowpea cropping. This research was conducted since 1987, on this study was arranged by randomized block design (RBD) which consisting two factors, namely the first factors is the treatment tillage system which consists of no tillage $\left(T_{0}\right)$, minimum tillage $\left(T_{p}\right)$, and intensive tillage ( $\left.T_{2}\right)$ whereas the second factor is without nitrogen ferfilizer residue $0 \mathrm{~kg} \mathrm{~N} \mathrm{ha}^{-1}\left(N_{0}\right)$, and $200 \mathrm{~kg}$ $\mathrm{N} \mathrm{ha}^{-1}\left(N_{p}\right)$ each experiment was repeated by 4 times. The data were analyzed using variance and continued with by BNT test $5 \%$, test the correlation between several soil properties and soil respiration. Observation of soil respiration was done by 5 times, the first sampling was done before tillage (SOT), the second times was done after tillage before planting, the third sampling was done on beginning vegetative (14 HST), the fourth sampling on maximum vegetative (65 HST), and the five sampling harvesting (90 HST). The result showed that soil respiration in the before tillage and beginning vegetative OTI was higher than TOT and OTM, whereas the maximum vegetative and harvesting was higher in TOT, the effect of long term $N$ fertilization residues on soil respiration, was none interaction between system tillage and $N$ fertilizer residue in soil respiration, and there are relations between soil temperature before tillage (SOT), soil C-organic before tillage (SOT), beginning vegetative (14 HST), and maximum vegetative (65 HST) with soil respiration.
\end{abstract}

Keywords: Nitrogen fertilizing residues, soil respiration, tillage system. 


\begin{abstract}
ABSTRAK
Salah satu cara agar tanah tetap subur adalah dengan pengelolaan tanah yang baik, dan sesuai dengan kaidah pertanian berkelanjutan yaitu dengan melakukan pengelolaan tanah konservasi dan pemupukan yang tepat. Tujuan penelitian ini adalah mempelajari pengaruh sistem olah tanah jangka panjang, residu pemupukan N jangka panjang, pengaruh interaksi sistem olah tanah dan residu pemupukan $\mathrm{N}$ jangka panjang terhadap laju respirasi tanah, serta mempelajari hubungan antara $\mathrm{C}$-organik tanah, kadar air tanah, $\mathrm{pH}$ tanah, dan suhu tanah dengan laju repirasi tanah pada pertanaman kacang tunggak. Penelitian yang sekarang berlangsung sejak 1987 ini disusun dalam Rancangan Acak Kelompok (RAK) yang terdiri dari dua faktor yaitu faktor pertama faktor sistem olah tanah yang terdiri dari tanpa olah tanah $\left(\mathrm{T}_{0}\right)$, olah tanah minimum $\left(\mathrm{T}_{1}\right)$, dan olah tanah intensif $\left(\mathrm{T}_{2}\right)$ sedangkan faktor kedua pemupukan nitrogen yang terdiri dari $0 \mathrm{~kg} \mathrm{~N} \mathrm{ha}^{-1}\left(\mathrm{~N}_{0}\right)$, dan $200 \mathrm{~kg} \mathrm{~N} \mathrm{ha}^{-1}\left(\mathrm{~N}_{1}\right)$ setiap satuan percobaan diulang 4 kali. Data dianalisis dengan sidik ragam dan dilanjutkan dengan Uji BNT taraf 5\%, uji korelasi antara beberapa sifat tanah dengan respirasi tanah. Pengamatan respirasi tanah dilakukan sebanyak 5 kali, yaitu sampel 1 sebelum olah tanah (SOT), sampel 2 setelah olah tanah sebelum tanam, sampel 3 vegetatif awal (14 HST), sampel 4 pada vegetatif maksimum (65 HST), dan sampel 5 panen (90 HST). Hasil penelitian menunjukkan bahwa respirasi tanah pada perlakuan sebelum tanam dan vegetatif awal OTI lebih tinggi dari pada TOT dan OTM, sedangkan pada vegetatif maksimum dan panen lebih tinggi pada TOT, pengaruh residu pemupukan $\mathrm{N}$ jangka panjang terhadap respirasi tanah tidak berpengaruh terhadap respirasi tanah, tidak terdapat interaksi antara sistem olah tanah dan residu pemupukan $\mathrm{N}$ dengan respirasi tanah, dan terdapat hubungan antara suhu tanah sebelum olah tanah (SOT), C-organik tanah pada sebelum olah tanah (SOT), vegetatif awal (14 HST), dan vegetatif maksimum (65 HST) dengan respirasi tanah.
\end{abstract}

Kata kunci : Residu pemupukan nitrogen, respirasi tanah, sistem olah tanah.

\section{PENDAHULUAN}

Tanaman kacang-kacangan diperlukan sebagai salah satu sumber protein, dan salah satunya merupakan kacang tunggak (Vigna unguiculata (L.). Tanaman kacang tunggak harus ditanam di lahan yang subur. Salah satu cara agar tanah tetap subur adalah dengan pengelolaan tanah yang baik, dan sesuai dengan kaidah pertanian berkelanjutan antara lain dengan melakukan pengolahan tanah konservasi dan pemupukan yang tepat.

OTK dapat dilakukan dengan sistem TOT atau OTM. Praktik OTK akan berbeda pengaruhnya terhadap kimia, fisika, dan biologi tanah (Utomo, 2006). Sistem TOT yaitu tanah tidak diolah, hanya gulma yang tumbuh di atasnya dikendalikan dengan herbisida yang baik untuk lingkungan, yang mudah terdekomposisi sehingga tidak merusak lingkungan (Utomo, 2015). Sedangkan sistem OTM merupakan salah satu sistem OTK yang dilakukan dengan mengolah tanah seminimal mungkin namun masih memberikan kondisi yang menguntungkan bagi pertumbuhan tanaman (Sutanto, 2002).

Nitrogen $(\mathrm{N})$, fosfor $(\mathrm{P})$, dan kalium $(\mathrm{K})$ merupakan unsur hara yang penting di dalam tanah. Penambahan pupuk $\mathrm{N}$ ke dalam tanah dapat meningkatkan atau menurunkan jumlah dan aktivitas mikroorganisme tanah. Hasil penelitian Fernando (2010), menyatakan bahwa sistem olah tanah intensif 
dengan pemupukan $\mathrm{N}$ maupun tanpa pemupukan $\mathrm{N}$ dapat mempercepat pelepasan $\mathrm{CO}_{2}$ ke udara.

OTK bahan organik dalam tanah akan lebih tinggi dari pada OTI, karena tanah tidak diolah, hanya saja gulma yang tumbuh diatasnya dikendalikan dengan herbisida layak lingkungan, yang mudah terdekomposisi sehingga tidak merusak lingkungan (Utomo, 2015). Selain itu Andayani (1999), menyatakan bahwa sistem olah tanah dapat mempengaruhi kuantitas $\mathrm{CO}_{2}$ dalam tanah. Sistem olah tanah maksimum membuat struktur tanah menjadi gembur, aerasi baik, sehingga dapat meningkatkan aktivitas mikroorganisme dan laju respirasi tanah, sehingga $\mathrm{CO}_{2}$ dilepas ke udara semakin tinggi. Berdasarkan uraian di atas, maka perlu dilakukan penelitian tentang pengaruh sistem olah tanah dan residu pemupukan $\mathrm{N}$ jangka panjang terhadap laju respirasi tanah pada pertanaman kacang tunggak (Vigna unguiculata (L.) di Politeknik Negeri Lampung.

\section{BAHAN DAN METODE}

Penelitian ini merupakan percobaan jangka panjang yang dimulai pada tahun 1987 dan saat ini merupakan tahun tanam ke-32 pada lahan Kebun Percobaan Politeknik Negeri Lampung yang berada pada $105^{\circ} 13^{\prime} 45,5^{\prime \prime}-105^{\circ} 13^{\prime} 48,0$ ' BT dan 05²1'19,7' LS, dengan elevasi 122 m dari permukaan laut (Utomo, 2012). Pengamatan ke-32 ini dilakukan pada bulan April 2019 sampai dengan Juli 2019. Analisis tanah dilakukan di Laboratorium Ilmu Tanah Fakultas Pertanian Universitas Lampung.

Penelitian disusun dalam Rancangan Acak Kelompok (RAK) yang terdiri dari dua faktor yaitu faktor pertama sistem olah tanah yang terdiri dari tanpa olah tanah $\left(\mathrm{T}_{0}\right)$, olah tanah, olah tanah intensif $\left(\mathrm{T}_{1}\right)$, dan olah tanah minimum $\left(\mathrm{T}_{2}\right)$ dan faktor kedua pemupukan nitrogen yang terdiri dari tanpa residu pemupukan $\mathrm{N}\left(\mathrm{N}_{0}\right)$, dan residu pemupukan nitrogen $200 \mathrm{~kg} \mathrm{ha}^{-1}\left(\mathrm{~N}_{1}\right)$ setiap satuan percobaan diulang 4 kali. Data yang diperoleh diuji homogenitasnya dengan Uji Bartlett dan aditifitasnya diuji dengan Uji Tukey. Selanjutnya data dianalisis dengan sidik ragam dan dilanjutkan dengan Uji BNT taraf 5\% dan uji korelasi.

Pada petak TOT tanah tidak diolah sama sekali. Gulma pada TOT yang tumbuh dikendalikan dengan herbisida berbahan aktif 2,4-D dimetil amina1 $\mathrm{L} \mathrm{ha}^{-1}$ dan herbisida berbahan aktif glifosat 3-5 $\mathrm{L} \mathrm{ha}^{-1}$, kemudian sisa tanaman dan gulma digunakan sebagai mulsa. Pada petak OTI tanah diolah dengan menggunakan cangkul hingga kedalaman 0-20 cm, sisa gulma dan tanaman dibuang dari petak percobaan. Penanaman benih kacang tunggak dilakukan dengan jarak tanam $75 \mathrm{~cm}$ x $25 \mathrm{~cm}$. Pengamatan respirasi tanah dilakukan dengan cara menyungkup permukaan tanah dengan toples dan di dalam toples tersebut terdapat botol film yang berisi $10 \mathrm{ml} 0,1 \mathrm{NKOH}$. Pada pengukuran blanko, permukaan tanah dilapisi oleh plastik. Hal ini bertujuan agar tidak ada udara atau $\mathrm{CO}_{2}$ yang masuk ke dalam toples. Pengukuran respirasi tanah dilakukan selama 2 jam pada setiap plot perlakuan dan dilakukan pada waktu pagi pukul 07.00 - 09.00 WIB dan sore pukul 15.00 - 17.00 WIB.

Setelah sampel diambil dari tiap plot, $10 \mathrm{ml} \mathrm{0,1}$ $N \mathrm{KOH}$ pada botol kemudian dipindahkan kedalam erlenmeyer dan ditetesi dengan dua tetes fenolptalin (terjadi perubahan warna ungu), kemudian dititrasi dengan $\mathrm{HCl} 0,1 \mathrm{~N}$ sampai warna ungu tersebut berubah 
menjadi bening. Selanjutnya ditambahkan dua tetes metil orange (terjadi perubahan menjadi warna orange) dan langsung dititrasi kembali dengan $\mathrm{HCl} \mathrm{0,1} \mathrm{N}$ sampai warna orange tersebut berubah warna menjadi warna merah muda (pink) Jumlah $\mathrm{CO}_{2}$ dari respirasi tanah dapat dihitung dengan menggunakan rumus sebagai berikut (Anas, 1989).

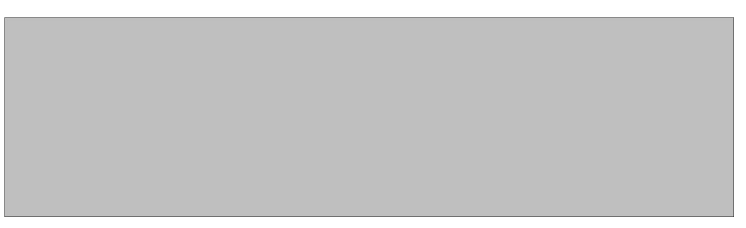

dengan $\mathrm{a}=\mathrm{ml} \mathrm{HCl} \mathrm{untuk} \mathrm{respirasi} \mathrm{tanah} \mathrm{(pada}$ permukaan tanah tanpa dilapisi dengan plastik), $b=\mathrm{ml}$
$\mathrm{HCl}$ untuk blanko (pada permukaan tanah dilapisi dengan plastik), $\mathrm{t}=$ normalitas $\mathrm{HCl} 0,1 \mathrm{~N}, \mathrm{~T}=$ waktu pengukuran (jam), $r=$ jari-jari toples $(m)$, dan $\partial=3,14$ Variabel pendukung yang diamati adalah Corganik Tanah, kadar air, suhu tanah, dan $\mathrm{pH}$ tanah.

\section{HASIL DAN PEMBAHASAN}

Hasil analisis ragam (Tabel 1) menunjukkan bahwa perlakuan residu pemupukan N jangka panjang tidak berpengaruh nyata terhadap respirasi tanah pada SOT tetapi perlakuan olah tanah berpengaruh terhadap respirasi tanah pada pengamatan sebelum tanam,

Tabel 1. Ringkasan data dan analisis ragam akibat pengaruh sistem olah tanah dan residu pemupukan $\mathrm{N}$ jangka panjang terhadap laju respirasi tanah pada tanaman kacang tunggak (Vigna unguiculata (L.)

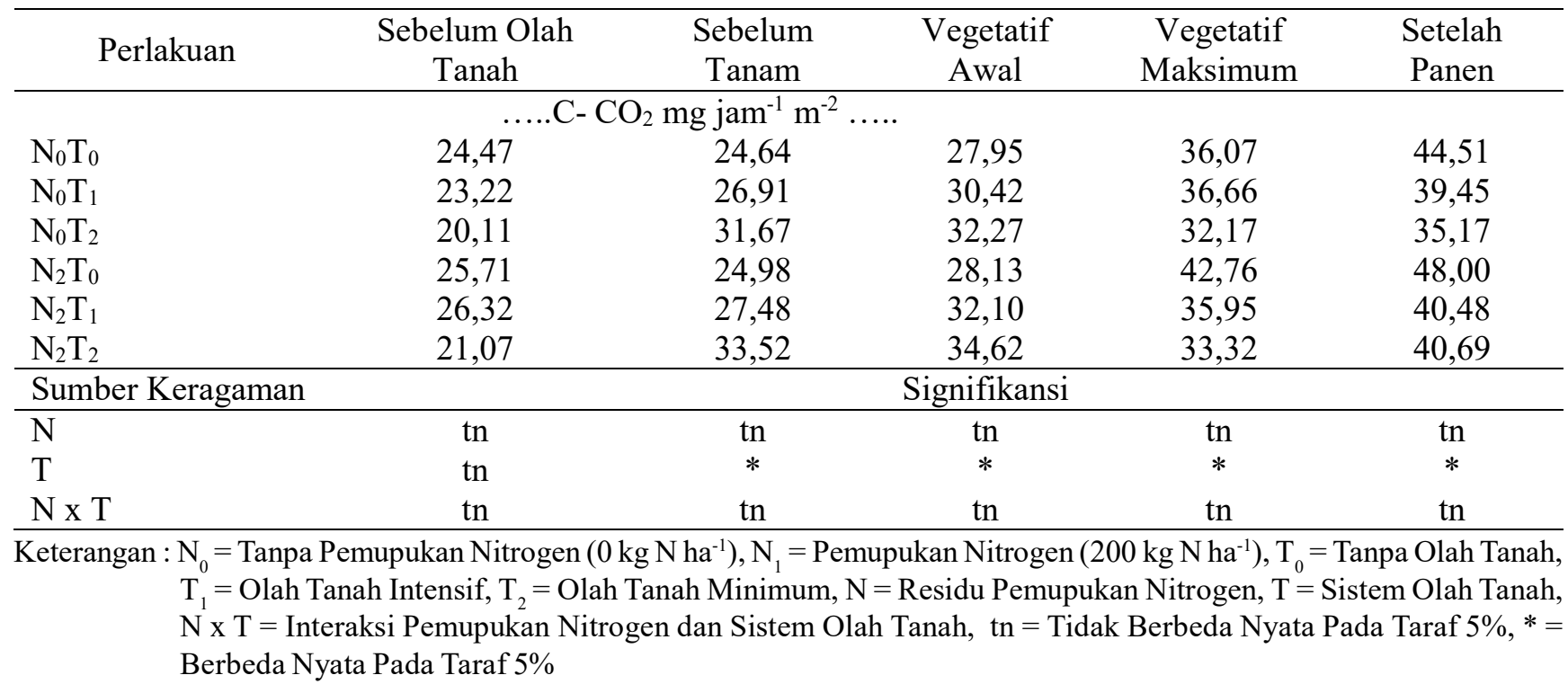

Tabel 2. Sistem olah tanah dan residu pemupukan $\mathrm{N}$ jangka panjang terhadap laju respirasi tanah pada tanaman kacang tunggak (Vigna unguiculata L.).

\begin{tabular}{ccccc}
\hline Perlakuan & Sebelum Tanam & Vegetatif Awal & Vegetatif Maksimum & Panen \\
\hline & & $\ldots . . \mathrm{C}-\mathrm{CO}_{2} \mathrm{mg} \mathrm{jam}^{-1} \mathrm{~m}^{-2} \ldots$. & & \\
$\mathrm{T}_{0}$ & $24,81 \mathrm{c}$ & $28,03 \mathrm{~b}$ & $39,41 \mathrm{a}$ & $46,25 \mathrm{a}$ \\
$\mathrm{T}_{1}$ & $27,19 \mathrm{~b}$ & $31,25 \mathrm{a}$ & $36,30 \mathrm{a}$ & $39,26 \mathrm{~b}$ \\
$\mathrm{~T}_{2}$ & $32,59 \mathrm{a}$ & $33,44 \mathrm{a}$ & $32,74 \mathrm{~b}$ & $37,93 \mathrm{~b}$ \\
\hline BNT $5 \%$ & 2,36 & 2,35 & 3,39 & 4,55
\end{tabular}

Keterangan : Angka yang diikuti oleh huruf yang sama tidak berbeda nyata menurut uji BNT pada Taraf $5 \%$. $\mathrm{N}_{0}=$ Tanpa Pemupukan Nitrogen $\left(0 \mathrm{~kg} \mathrm{~N}^{-1}\right), \mathrm{N}_{1}=$ Pemupukan Nitrogen $\left(200 \mathrm{~kg} \mathrm{~N} \mathrm{ha}^{-1}\right), \mathrm{T}_{0}=$ Tanpa Olah Tanah, $\mathrm{T}_{1}=$ Olah Tanah Minimum, $\mathrm{T}_{2}=$ Olah Tanah Intensif. 
vegetatif awal, vegetatif maksimum, dan panen, serta tidak adanya interaksi pada perlakuan residu pemupukan $\mathrm{N}$ jangka panjang dan olah tanah terhadap respirasi tanah.

Hasil uji BNT 5\% (Tabel 2) menunjukkan bahwa respirasi tanah pada pengamatan sebelum tanam lebih tinggi pada OTI dibandingkan dengan OTM dan TOT, serta OTM lebih tinggi daripada TOT. Selanjutnya pada pengamatan vegetatif awal respirasi tanah lebih tinggi daripada OTM dan OTI. Sedangkan pada pengamatan vegetatifmaksimum respirasi tanah TOT dan OTM tidak berbeda nyata tetapi nyata lebih tinggi dari OTI. Selanjutnya pada pengamatan panen respirasi tanah TOT nyata lebih tinggi daripada OTM dan OTI, sementara OTM dan OTI tidak berbeda nyata.

Pada penelitian yang telah dilakukan sifat fisika tanah yang diamati yaitu suhu tanah dan kadar air tanah, sedangkan sifat kimia tanah yang diamati yaitu $\mathrm{C}$-organik tanah dan $\mathrm{pH}$ tanah. Hasil analisis ragam (Tabel 3) menunjukkan bahwa perlakuan residu pemupukan $\mathrm{N}$ jangka panjang berpengaruh terhadap $\mathrm{pH}$ tanah pada pengamatan vegetatif awal, vegetatif maksimum, dan panen. Sementara itu pada perlakuan residu pemupukan $\mathrm{N}$ jangka panjang dan olah tanah pada pengamatan vegetatif awal, vegetatif maksimum, dan panen tidak berpengaruh terhadap C-organik tanah, kadar air tanah, dan suhu tanah, serta tidak terdapat pengaruh interaksi antara perlakuan residu pemupukan $\mathrm{N}$ jangka panjang dan olah tanah terhadap respirasi tanah. Pada pengamatan hasil uji korelasi menunjukkan bahwa respirasi SOT tidak berkorelasi dengan kadar air tanah dan $\mathrm{pH}$ tanah, namun berkorelasi dengan suhu tanah dan C-organik tanah. Pada respirasi sebelum tanam tidak berkorelasi pada

Tabel 3. Hasil analisis sifat fisika dan kimia tanah pada tanaman kacang tunggak (Vigna unguiculata L.)

\begin{tabular}{|c|c|c|c|c|c|c|c|c|c|c|}
\hline \multirow{2}{*}{$\begin{array}{c}\text { Variabel } \\
\text { Pendukung }\end{array}$} & & \multicolumn{6}{|c|}{ Perlakuan } & \multicolumn{3}{|c|}{ Signifikansi } \\
\hline & & $\mathrm{N}_{0} \mathrm{~T}_{0}$ & $\mathrm{~N}_{0} \mathrm{~T}_{1}$ & $\mathrm{~N}_{0} \mathrm{~T}_{2}$ & $\mathrm{~N}_{1} \mathrm{~T}_{0}$ & $\mathrm{~N}_{1} \mathrm{~T}_{1}$ & $\mathrm{~N}_{1} \mathrm{~T}_{2}$ & $\mathrm{~N}$ & $\mathrm{~T}$ & $\mathrm{NxT}$ \\
\hline \multirow{3}{*}{$\begin{array}{c}\text { C-Organik } \\
\text { Tanah } \\
(\%)\end{array}$} & $\begin{array}{c}\text { Vegetatif } \\
\text { awal }\end{array}$ & $1,11(\mathrm{r})$ & $1,17(\mathrm{r})$ & $1,12(\mathrm{r})$ & $1,21(\mathrm{r})$ & $1,16(\mathrm{r})$ & $1,14(\mathrm{r})$ & tn & tn & tn \\
\hline & $\begin{array}{l}\text { Vegetatif } \\
\text { maks }\end{array}$ & $1,78(\mathrm{r})$ & $1,79(\mathrm{r})$ & $1,59(\mathrm{r})$ & $1,85(\mathrm{r})$ & $1,75(\mathrm{r})$ & $1,53(\mathrm{r})$ & tn & tn & tn \\
\hline & Panen & $1,45(\mathrm{r})$ & $1,58(\mathrm{r})$ & $1,49(\mathrm{r})$ & $1,69(\mathrm{r})$ & $1,55(\mathrm{r})$ & $1,39(\mathrm{r})$ & tn & tn & tn \\
\hline \multirow{3}{*}{$\begin{array}{c}\text { Kadar Air } \\
\text { Tanah } \\
(\%)\end{array}$} & $\begin{array}{c}\text { Vegetatif } \\
\text { awal }\end{array}$ & 35,81 & 35,60 & 33,98 & 39,06 & 35,59 & 36,32 & tn & tn & tn \\
\hline & $\begin{array}{l}\text { Vegetatif } \\
\text { maks }\end{array}$ & 35,91 & 36,99 & 34,48 & 37,11 & 37,45 & 34,51 & tn & tn & tn \\
\hline & Panen & 28,44 & 27,82 & 27,64 & 27,77 & 28,16 & 29,42 & tn & tn & tn \\
\hline \multirow{3}{*}{$\begin{array}{c}\mathrm{pH} \text { Tanah } \\
\left(\mathrm{H}_{2} \mathrm{O}\right)\end{array}$} & $\begin{array}{c}\text { Vegetatif } \\
\text { awal }\end{array}$ & $6,63(\mathrm{n})$ & $6,60(n)$ & $6,73(\mathrm{n})$ & $6,20(\mathrm{am})$ & $6,15(\mathrm{am})$ & 6,16 (am) & $*$ & tn & tn \\
\hline & $\begin{array}{l}\text { Vegetatif } \\
\text { maks }\end{array}$ & $6,69(\mathrm{n})$ & $6,79(\mathrm{n})$ & $6,63(\mathrm{n})$ & $6,21(\mathrm{am})$ & 6,17 (am) & $6,20(\mathrm{am})$ & $*$ & tn & tn \\
\hline & Panen & 5,96 (am) & $6,11(\mathrm{am})$ & $6,06(\mathrm{am})$ & $5,76(\mathrm{am})$ & 5,71 (am) & $5,61(\mathrm{am})$ & $*$ & tn & tn \\
\hline \multirow{3}{*}{$\begin{array}{l}\text { Suhu Tanah } \\
\left({ }^{\circ} \mathrm{C}\right)\end{array}$} & $\begin{array}{c}\text { Vegetatif } \\
\text { awal }\end{array}$ & 27,25 & 27,75 & 27,75 & 27,50 & 28,50 & 28,00 & tn & tn & tn \\
\hline & $\begin{array}{l}\text { Vegetatif } \\
\text { maks }\end{array}$ & 27,50 & 27,50 & 28,00 & 26,75 & 27,25 & 27,75 & tn & tn & tn \\
\hline & Panen & 26,50 & 26,75 & 27,25 & 27,25 & 27,00 & 27,50 & tn & tn & tn \\
\hline
\end{tabular}

Keterangan : $\mathrm{N}_{0}=$ Tanpa Pemupukan Nitrogen $\left(0 \mathrm{~kg} \mathrm{~N} \mathrm{ha}^{-1}\right), \mathrm{N}_{1}=$ Pemupukan Nitrogen $\left(200 \mathrm{~kg} \mathrm{~N} \mathrm{ha}^{-1}\right)$, $\mathrm{T}_{0}=$ Tanpa Olah Tanah, $\mathrm{T}_{1}=$ Olah Tanah Minimum, $\mathrm{T}_{2}=$ Olah Tanah Intensif, $\mathrm{N}=$ Residu Pemupukan Nitrogen, $\mathrm{T}=$ Sistem Olah Tanah, N x T = Interaksi Pemupukan Nitrogen dan Sistem Olah Tanah, tn = Tidak Berbeda Nyata Pada Taraf 5\%, * = Berbeda Nyata Pada Taraf 5\% ; r = Rendah, $\mathrm{n}=$ Netral, am = Agak Masam 
suhu tanah, kadar air tanah, $\mathrm{pH}$ tanah dan C-organik tanah. Pada respirasi vegetatif awal tidak berkorelasi pada suhu tanah, kadar air tanah, dan $\mathrm{pH}$ tanah, namun berkorelasi pada C-organik tanah. Pada respirasi vegetatif maksimum tidak berkorelasi dengan suhu tanah, kadar air tanah, dan $\mathrm{pH}$ tanah, namun berkorelasi dengan C-organik tanah sedangkan pada respirasi panen tidak berkorelasi dengan suhu tanah, kadar air tanah, $\mathrm{pH}$ tanah, dan C-organik tanah.

Pada pengambilan sampel hasil pengamatan SOT menunjukkan bahwa perlakuan sistem olah tanah (TOT, OTI, dan OTM) dan residu pemupukan N tidak berpengaruh terhadap respirasi tanah. Hal tersebut diduga karena terjadinya proses pemberaan lahan yang terlalu lama dan kondisi tanah yang kering. Kondisi tersebut dikarenakan tidak adanya hujan yang mengakibatkan kelembaban tanah (Syahrinuddin, 2005). Menurut Hanafiah (2004), kelembaban tanah mempengaruhi dominasi jenis mikroorganisme tanah yang aktif dalam proses dekomposisi bahan organik tanah. Pada kelembaban tanah yang tinggi, perkembangan dan aktivitas mikroorganisme tanah akan maksimum. Sebaliknya akan menurun pada kondisi kering dan sangat tertekan pada kadar air titik layu permanen. Oleh karena itu kelembaban tanah pada semua perlakuan sistem olah tanah (TOT, OTI, dan OTM) tidak berbeda nyata sehingga pengaruhnya sama. Kelembaban tanah yang kering pada sistem TOT dikarenakan tidak dilakukan pengolahan tanah sama sekali, namun memiliki mikroorganisme tanah yang banyak. Sehingga mengakibatkan kelembaban tanah menjadi kering dan mikroorganisme didalam tanah menjadi dorman dan sedikit yang beraktivitas.
Menurut Utomo (2012), kelembaban tanah pada kondisi kering dapat menyebabkan mikroba tanah menjadi dorman atau mikroba membentuk spora sehingga respirasi tanah menurun tajam.

Sebaliknya pada sistem OTI dilakukan pengolahan tanah dengan pencangkulan dua kali atau lebih sedalam 0-20 cm dan permukaan tanah bersih dari gulma dan mulsa, lapisan olah tanah diusahakan cukup gembur agar perakaran tanaman dapat berkembang dengan baik, dan memudahkan penanaman benih. Kelembaban kering pada sistem OTI menyebabkan permukaan tanah tidak mampu menahan laju aliran air permukaan yang mengalir deras, sehingga banyak mikroorganisme tanah yang hilang terbawa aliran air permukaan yang dapat menyebabkan mikroorganisme tanah menjadi sedikit. Utomo (2012), menyatakan bahwa sistem OTI memiliki permukaan tanah yang bersih dan gembur tetapi tidak mampu menahan laju aliran permukaan yang mengalir deras. Sehingga partikel tanah yang mengandung humus, hara, dan banyak biota tanah tergerus oleh air ke hilir. Selain itu, di daerah tropika basah seperti di Indonesia, sistem OTI di lahan kering justru memacu erosi dan mempercepat pelapukan bahan organik tanah. Akibatnya, kesuburan tanah in situ dapat terkuras dan produktivitas lahan untuk jangka panjang dapat menurun. Dengan demikian respirasi tanah yang dihasilkan pada perlakuan sistem TOT dan OTI adalah sama.

Pada sistem OTM dilakukan pengolahan tanah seminimal mungkin tetapi masih memberikan kondisi yang menguntungkan bagi pertumbuhan tanaman (Sutanto, 2002). Pada sistem OTM, tanah diolah hanya pada bagian penanaman tanaman, sedangkan 
areal yang tidak dilakukan pengolahan biasanya akan ditumbuhi banyak gulma. Selain itu, pada sistem OTM apabila pertumbuhan gulma tidak terlalu banyak dapat dilakukan secara manual (dibesik), tetapi apabila pengendalian manual tidak berhasil maka dapat dipadukan dengan penggunaan herbisida (Utomo, 2012).

Hasil penelitian (Tabel2) menunjukkan bahwa OTI dan OTM pada respirasi tanah sebelum tanam dan vegetatif awal lebih tinggi dibandingkan dengan TOT. Hal ini diduga adanya pengaruh pengolahan tanah. Pengolahan tanah yang dilakukan selama penelitian secara intensif. Lapisan tanah cukup gembur, namun tidak mampu menahan laju aliran air permukaan yang mengalir deras. Sehingga banyak pertikel tanah yang mengandung humus dan hara tergerus yang selanjutnya terbawa oleh air. Oleh karena laju evaporasi cukup tinggi maka lapisan olah tanah yang tanpa ditutupi dengan mulsa tersebut tidak mampu menahan aliran uap air ke atas (atmosfer). Sehingga mengakibatkan $\mathrm{O}_{2}$ masuk kedalam tanah dan banyak mikroorganisme tanah kontak terhadap partikel tanah, dan mengakibatkan aerasi meningkat sehingga pelapukan bahan organik tanah menghasilkan gas $\mathrm{CO}_{2}$ meningkat dan respirasi tanah yang dihasilkan pun meningkat. Peningkatan $\mathrm{O}_{2}$ di dalam tanahdapatmeningkatkan aktivitas mikroorganisme tanah dalammendekomposisi bahan organik tanah. Selain itu, keadaan aerasi tanah yang baik lebih memudahkan $\mathrm{O}_{2}$ masuk ke dalam tanah. Pada saat terjadi penguraian bahan organik tanah, banyak unsur karbon $\mathrm{CO}_{2}$ yang hilang ke udara (Aksi Agraris Konisius, 1992), karena tidak adanya mulsa.

Selanjutnya, hasil penelitian (Tabel 2) menunjukkan bahwa perlakuan TOT pada respirasi tanah vegetatif maksimum dan panen lebih tinggi dibandingkan dengan OTI dan OTM. Hal ini diduga karena sistem TOT dapat meningkatkan C (karbon) dalam tanah pertanian tanaman pangan, karena dalam persiapan lahannya TOT menggunakan residu tanaman minimal 30\% sebagai bahan organik (Utomo, 2004). Berdasarkan penelitian Utomo (2012), karbon pada sistem TOT dengan kedalam tanah 0-20 cm lebih tinggi $\left(37,8 \mathrm{~kg} \mathrm{Cha}^{-1}\right)$. Penyerapan karbon dalam biomassa pertanian pada sistem OTK lebih besar dibandingkan dengan penyerapan karbon yang ada di hutan, karena karbon yang tersimpan didalam tanah adalah bagian dari siklus karbon yang merupakan hasil bersih dari penambahan karbon tanah hasil dekomposisi residu tanaman dan pengurangan karbon tanah akibat emisi

Tabel 4. Hubungan antara C-organik tanah, kadar air tanah, $\mathrm{pH}$ tanah, dan suhu tanah dengan respirasi tanah pada beberapa fase pertanaman kacang tunggak (Vigna unguiculata(L.).

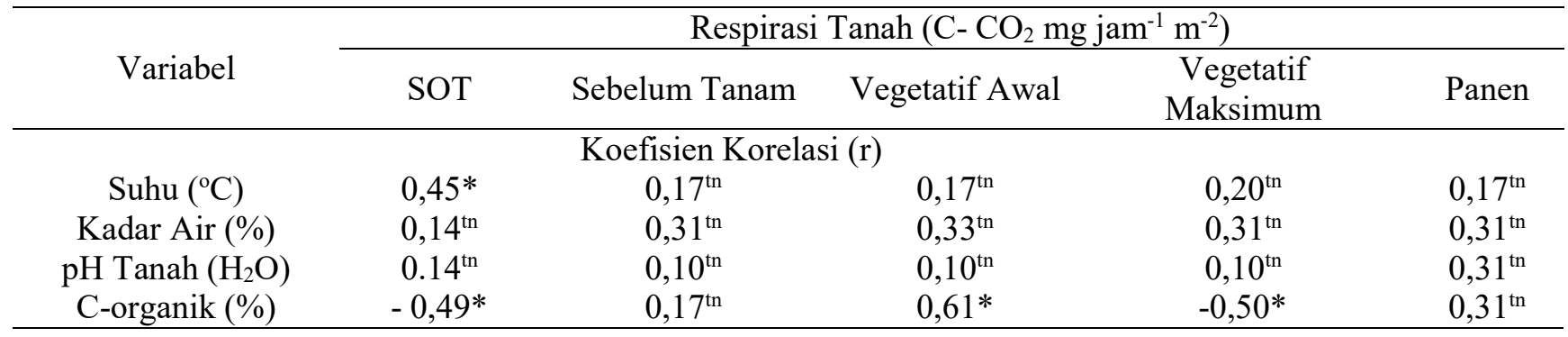

Keterangan : $\mathrm{tn}=$ Tidak Berkorelasi Nyata pada Taraf 5\%, * = Berkorelasi Nyata pada Taraf 5\%, $\mathrm{r}=$ Koefisien Korelasi 
gas $\mathrm{CO}_{2}$ akibat erosi. Umumnya sistem TOT dapat menguntungkan untuk pertanian jangka panjang.

Hasil ringkasan uji korelasi (Tabel 4) menunjukkan bahwa respirasi tanah tidak berkorelasi dengan kadar air tanah dan $\mathrm{pH}$ tanah, namun berkorelasi dengan suhu tanah dan C-organik tanah . Pada respirasi tanah secara nyata berkorelasi dengan suhu tanah dan C-organik tanah. C-organik mempunyai peranan yang penting di dalam tanah, yaitu terhadap sifat-sifat tanah (Reeves, 1997) sedangkan

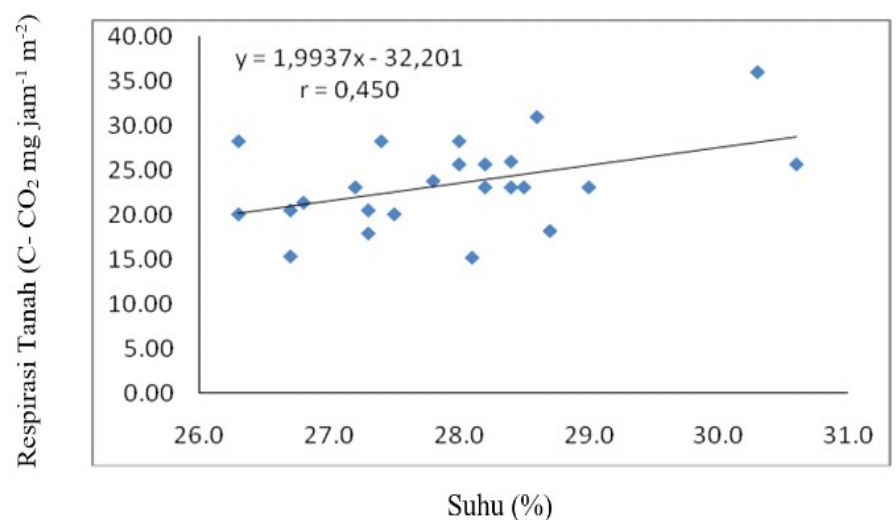

Gambar 1. Hubungan antara suhu dengan respirasi tanah sebelum olah tanah pertanaman kacang tunggak (Vigna unguiculata (L.).

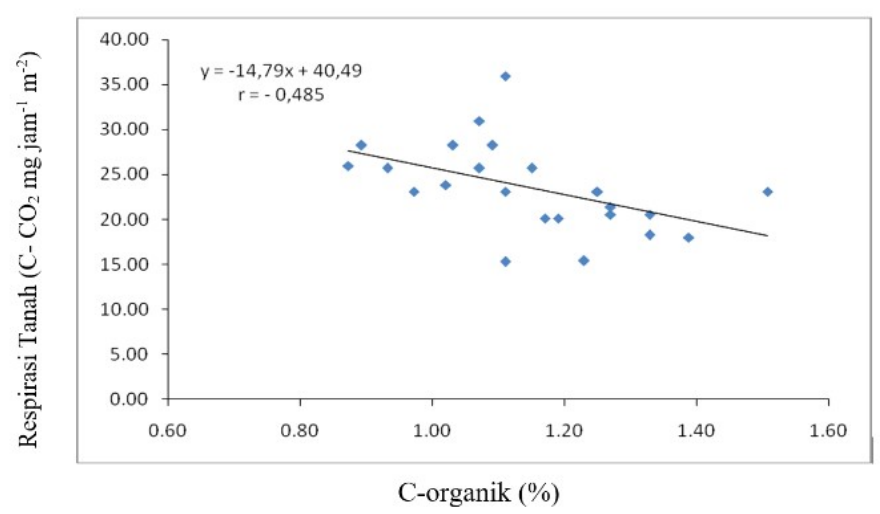

Gambar 2. Hubungan antara C-organik dengan respirasi tanah sebelum olah tanah pertanaman kacang tunggak (Vigna unguiculata (L.).

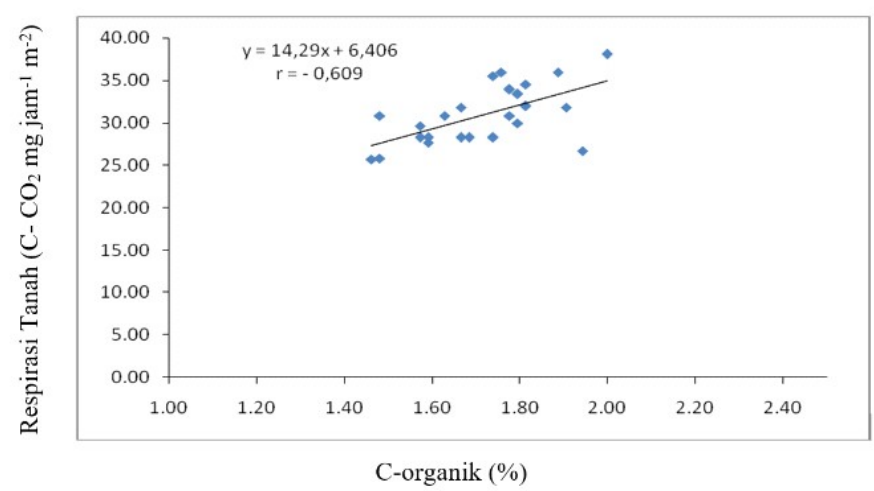

Gambar 3. Hubungan antara C-organik dengan respirasi tanah vegetatif awal pertanaman kacang tunggak (Vigna unguiculata (L.). 


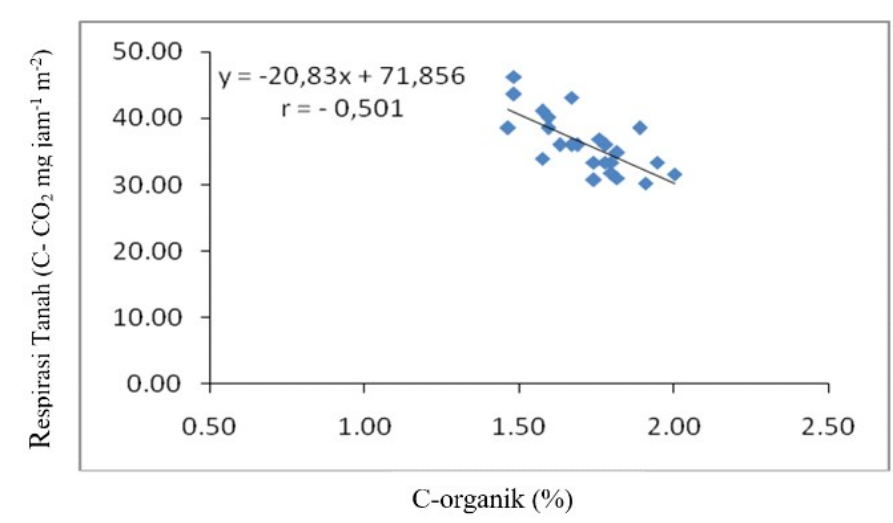

Gambar 4. Hubungan antara C-organik dengan respirasi tanah vegetatif maksimum pertanaman kacang tunggak (Vigna unguiculata (L.).

suhu merupakan salah satu faktor penting pada proses respirasi tanah (Irawan dan June, 2011). Menurut Megharaj dkk. (1999), perubahan suhu tanah pada setiap pengolahan tanah berpengaruh pada emisi $\mathrm{CO}_{2}$ tanah. Perubahan suhu tanah secara langsung berpengaruh terhadap laju reaksi fisik dalam tanah dan secara tidak langsung dapat berpengaruh terhadap aktivitas mikrobia tanah melalui laju pelapukan mineral, laju difusi, potensi redoks, aktivitas air.

\section{KESIMPULAN}

Berdasarkan hasil penelitian dapat disimpulkan bahwa respirasi tanah pada perlakuan sebelum tanam dan vegetatif awal OTI lebih tinggi daripada TOT dan OTM, sedangkan pada vegetatif maksimum dan panen lebih tinggi pada TOT, pengaruh residu pemupukan $\mathrm{N}$ jangka panjang terhadap respirasi tanah tidak berpengaruh terhadap respirasi tanah, tidak terdapat interaksi antara sistem olah tanah dan residu pemupukan $\mathrm{N}$ terhadap respirasi tanah, dan terdapat hubungan suhu tanah sebelum olah tanah, C-organik tanah pada sebelum olah tanah, vegetatif awal, dan vegetatif maksimum dengan respirasi tanah.

\section{DAFTAR PUSTAKA}

Aksi Agraris Konisius (AAK). 1992. Dasar-Dasar Bercocok Tanam. Yogyakarta: Kanisius. 218 hlm.

Anas, I. 1989. Biologi Tanah Dalam Praktek. Pusat Antar Universitas Bioteknologi. Institut Pertanian Bogor. Bogor. $161 \mathrm{hlm}$.

Andayani, W. 1999. Optimalisasi Pemanfaatan Lahan Usaha Tani Pola Agroforestry. Jurnal Hutan Rakyat, 4(1): 55-67.

Hanafiah, K.A. 2004. Mikrobiologi Tanah. Diktat Kuliah pada Jurusan Tanah FP/Biologi MIPA/ FKIP Unsri, Indralaya, Sumsel.

Irawan, A., dan June, T. 2011. Hubungan Iklim Mikro dan Bahan Organik Tanah dengan Emisi CO2 dari Permukaan Tanah di Hutan Alam Babahaleke

Taman Nasional Lore Lindu, Sulawesi Tengah. Jurnal Agromet, 25(1): 1-8.

Megharaj, M., Boul, H. L., dan Thiele, J. H. 1999. Effects ofDDT and its metabolites on soil algae and enzymatic activity. Biology and Fertility of Soils, 29(2): 130-134. 
Reeves.W. 1997. The role of soil organic matter in maintaining soil quality in continuous cropping system. Soil and Tillage Research, 43: 131-167.

Sutanto, R. 2002. Penerapan Pertanian Organik. Permasyarakatan dan Pengembangannya. Penerbit Kanisius. Yogyakarta. $219 \mathrm{hlm}$.

Syahrinuddin. 2005. The Potential of Oil Palm and Forest Plantations for Carbon Sequestration on Degraded Land in Indonesia. Ecology and Development Series No.28. Cuvillier Verlag Gottingen. $107 \mathrm{hlm}$.

Utomo, M. 2015. Tanpa Olah Tanah; Teknologi Pengolahan Pertanian Lahan Kering. Graha Ilmu. Yogyakarta. $157 \mathrm{hlm}$.
Utomo, M. 2012. Tanpa Olah Tanah. Teknologi Pengelolaan Pertanian Lahan Kering. Lembaga Penelitian Universitas Lampung. $110 \mathrm{hlm}$.

Utomo, M. 2006. Olah Tanah Konservasi. Pengelolaan Lahan Kering Berkelanjutan. Universitas Lampung. $25 \mathrm{hlm}$.

Utomo, M. 2004. Olah Tanah Konservasi Untuk Budidaya Jagung Berkelanjutan. Prosiding Seminar Nasional IX Budidaya Pertanian Olah Tanah Konservasi. Gorontalo, 6-7 Oktober, 2004, pp. 18-35. 